\title{
UJI KELAYAKAN MEDIA URISCRAP (URI SCRAPBOOK) MENGGUNAKAN MODEL PENGEMBANGAN 4D
}

\author{
Nurlaili Rosyidah $^{1}$, Jefri Nur Hidayat ${ }^{2}$, Lutfiana Fazat Azizah ${ }^{3}$ \\ Program Studi Pendidikan Ilmu Pengetahuan Alam, Universitas Wiraraja ${ }^{1,2,3}$ \\ nurlailirosyidah@gmail.com ${ }^{1}$, jefryayak@gmail.com ${ }^{2}$, rumahkuindonesia@gmail.com ${ }^{3}$
}

\begin{abstract}
ABSTRAK
Penelitian uji kelayakan media uriscrap ini bertujuan untuk mengetahui kelayakan media uriscrap berdasarkan teknik penilaian dalam model pengembangan model 4D yang terdiri dari aspek materi dan bahasa, aspek media dan desain, dan aspek format. Metode penelitian yang digunakan merupakan penelitian dan pengembangan dengan mengikuti prosedur dalam model pengembangan 4D. Teknik pengumpulan data yang digunakan merupakan instrumen penelitian dengan analisis data kuantitatif. Hasil kelayakan yang diperoleh terhadap uji kelayakan media uriscrap berdasarkan aspek materi dan bahasa sebesar 91,11\%; aspek media dan desain sebesar 93,33\%; dan aspek format sebesar 97,22\% dengan kriteria sangat layak untuk masing-masing aspek. Uji kelayakan media uriscrap menunjukkan kriteria sangat layak sehingga media uriscrap ini layak untuk diuji cobakan sebelum nantinya dapat digunakan sebagai media pembelajaran dalam proses pembelajaran IPA kelas VII SMP.
\end{abstract}

Kata Kunci: uriscrap, kelayakan, $4 D$

\section{ABSTRACT}

This uriscrap media feasibility study aims to determine the feasibility of uriscrap media based on assessment techniques in the $4 D$ model development model consisting of material and language aspects, media and design aspects, and format aspects. The research method used is research and development by following the procedures in the 4D development model. Data collection techniques used are research instruments with quantitative data analysis. The feasibility results obtained from the feasibility test of uriscrap media are based on material and language aspects of 91.11\%; media and design aspects are 93.33\%; and the format aspect is $97.22 \%$ with very feasible criteria for each aspect. Uriscrap media feasibility test shows the criteria are very feasible so that the uriscrap media is feasible to be tested before it can be used as a learning media in the science learning process of grade VII junior high school.

Keywords: uriscrap, feasibility, $4 D$

\section{PENDAHULUAN}

Media uriscrap merupakan produk hasil pengembangan yang ditujukan sebagai media pembelajaran yang menekankan pada konsep dan fakta dalam pembelajaran IPA kelas VII SMP. Pengembangan media uriscrap didasarkan pada permasalahan dalam proses pembelajaran IPA di SMPN 2 Sumenep yang diperoleh informasi bahwa proses pembelajaran IPA masih jarang dalam penggunaan media pembelajaran. Hal ini dikarenakan keterbatasan waktu yang dimiliki guru dalam mengintegrasikan materi yang akan disampaikan dengan menggunakan media pembelajaran. Kurangnya penggunakan media dalam prosesr pembelajaran IPA menjadi salah 
satu faktor yang berpengaruh terhadap prestasi siswa yaitu 54\% siswa memiliki nilai dibawah rata-rata kumulatif kelas. Pemanfaatan media pengajaran pada hakekatnya bertujuan untuk meningkatkan efisiensi dan efektivitas pengajaran dalam membantu siswa mencerna dan memahami suatu pelajaran (Umar, 2013)

Pemilihan media uriscrap sebagai media pembelajaran didasarkan pada analisis siswa yang telah terbiasa dengan scrapbooking sebagai kegiatan menempel lembar jawaban atas pengayaan yang ada pada modul pegangan siswa. Media pembelajaran ini difokuskan pada gambar sebagai ilustrasi materi pembelajaran yang menyerupai objek/situasi yang nyata.

Proses pembelajaran IPA merupakan proses pembelajaran yang menekankan pada konsep dan fakta mengenai ilmu alam (Hidayat, Lesmanawati, and Maknun 2014). Penggunaan media uriscrap dalam proses pembelajaran IPA diharapkan akan dapat membantu siswa dalam belajar IPA untuk belajar konsep dan fakta.

Sebelum media uriscrap dapat digunakan sebagai media pembelajaran, maka media perlu diuji kelayakannya dari aspek materi dan bahasa, aspek media dan desain, dan aspek format. Hal ini sesuai dengan teori (Sivasailam Thiagarajan, Semmel, and Semmel 1974) terdapat tiga teknik penilaian terhadap produk yang dikembangkan yaitu penilaian bahasa, penilaian media, dan penilaian format.

Hasil penelitian (Safitri and Julianto, 2017) menyatakan bahwa "penggunaan media scrapbook digunakan sebagai jenis media konkret yang dikemas dalam bentuk sebuah buku yang menarik". Penelitian pengembangan ini didukung oleh penelitian (Ariyani and Siradjuddin, 2014) yang menyatakan bahwa media scrapbook dalam model pembelajaran langsung dapat meningkatkan hasil belajar siswa pada pembelajaran Ilmu Pengetahuan Sosial (IPS). Selaras dengan hasil penelitian (Fitrianthi, 2013) menunjukkan bahwa media scrapbook efektif dalam upaya meningkatkan pemahaman siswa terhadap pembelajaran membaca novel remaja.

Berdasarkan uraian permasalahan yang tersaji dan penelitian terdahulu mengenai scrapbook sebagai media pembelajaran, maka penelitian ini dilakukan untuk menguji kelayakan media uriscrap pada matapelajaran IPA untuk kelas VII SMP. Uji kelayakan terhadap media uriscrap bertujuan untuk menghasilkan media pembelajaran yang layak untuk digunakan sebagai media dalam proses pembelajaran IPA berdasarkan aspek keilmuan dan kebahasaan, aspek media dan desain, dan aspek format.

\section{METODE}

Uji kelayakan media uriscrap dilakukan dengan menggunakan metode penelitian dan pengembangan pada model yang dikembangkan oleh (Sivasailam Thiagarajan, Semmel, and Semmel 1974) yaitu model 4D dengan jenis data kuantitatif. Prosedur yang diterapkan dalam penelitian ini hanya sampai pada penilaian ahli (expert appraisal). Rancangan pengembangan media uriscrap sebagai berikut:

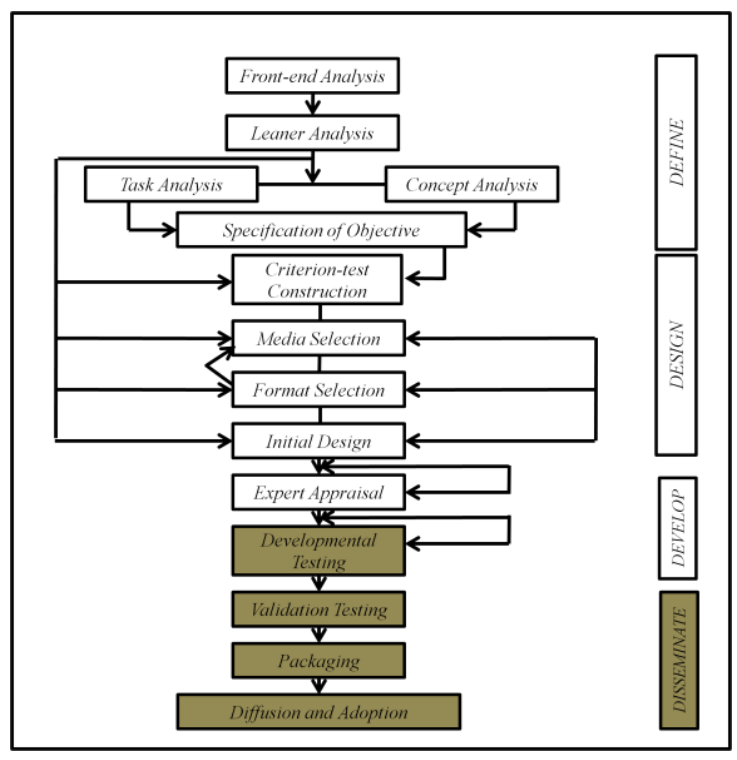

Gambar 1 Prosedur model pengembangan $4 \mathrm{D}$ 
Teknik pengumpulan data dalam uji kelayakan media uriscrap ini menggunakan instrumen penelitian dari aspek kelayakan menurut (BNSP 2014) dan (Sivasailam Thiagarajan, Semmel, and Semmel 1974) dengan menggunakan teknik analisis data sebagai berikut:

Menentukan rata-rata skor tiap kriteria:

$$
S K_{i}=\frac{\sum_{h=1}^{n 1} S_{h i}}{S M K_{i}} \times 100 \%
$$

Menentukan nilai akhir:

$$
N A=\frac{\sum_{i=1}^{n 2} S K_{i}}{n_{2}}
$$

Tabel 1 Kriteria aspek kelayakan media uriscrap

\begin{tabular}{ccc}
\hline Presentase yang Diperoleh & Kriteria & Keterangan \\
\hline $75 \% \leq \mathrm{x} \leq 100 \%$ & Sangat sesuai & Layak dan tidak revisi \\
\hline $50 \% \leq \mathrm{x}<75 \%$ & Sesuai & Cukup layak dan sedikit revisi \\
\hline $25 \% \leq \mathrm{x}<50 \%$ & Kurang sesuai & Kurang layak dan banyak revisi \\
\hline $0 \% \leq \mathrm{x}<25 \%$ & Tidak sesuai & Tidak layak dan revisi total \\
\hline
\end{tabular}

\section{HASIL}

Hasil uji kelayakan media uriscrap berdasarkan instrument penilaian yang dilakukan oleh ahli materi dan bahasa, ahli
Keterangan:

$S K_{i}=$ Persentase rata-rata skor kriteria ke $i$

$n_{i} \quad=$ Banyak validator

$S_{h i}=$ Skor yang diberikan oleh validator ke $h$

$S M K_{i}=$ Skor maksimum kriteria ke $i$

$N A=$ Rata-rata total kelayakan dari semua kriteria

$n_{2} \quad=$ Banyak kriteria yang dinilai pada kriteria ke $i$

Persentase hasil analisis data akan dideskripsikan menggunakan kriteria kelayakan pada tabel 1 sebagai berikut:

Tabel 2 Hasil data dari ahli keilmuan dan kebahasaan

\begin{tabular}{clcc}
\hline Bidang & \multicolumn{1}{c}{ Indikator } & Nilai (\%) & \multicolumn{1}{c}{ Kriteria } \\
\hline \multirow{2}{*}{ Materi } & Kesesuaian materi dengan KI dan KD & 96,30 & Sangat sesuai \\
\cline { 2 - 4 } & Keakuratan materi & 95,14 & Sangat sesuai \\
\cline { 2 - 4 } & Teknik penyajian & 87,15 & Sangat sesuai \\
\cline { 2 - 4 } & Pendukung materi pembelajaran & 87,50 & Sangat sesuai \\
\hline \multirow{2}{*}{ Bahasa } & Komunikatif & 92,36 & Sangat sesuai \\
\cline { 2 - 4 } & Lugas & 91,67 & Sangat sesuai \\
\cline { 2 - 4 } & Kesesuaian dengan tingkat perkembangan siswa & 90,28 & Sangat sesuai \\
\hline \multicolumn{2}{c}{ Jumlah } & 91,48 & Sangat sesuai \\
\hline
\end{tabular}

Data dari ahli keilmuan dan kebahasaan dalam media uriscrap pada tabel 2 menunjukkan hasil uji kelayakan terhadap materi dan bahasa diperoleh data sebesar 91,11\% dengan kriteria sangat sesuai. Kriteria sangat sesuai dapat diartikan bahwa materi dan bahasa cakupan dalam produk uriscrap telah layak dan tidak media dan desain, dan ahli format diperoleh hasil yang dapat dilihat pada tabel 2 sebagai berikut: revisi (Handayani, Yuwono, and Madja 2013). Proses kelayakan materi pada media uriscrap berlangsung dengan memperhatikan komentar dan saran dari ahli materi dan bahasa serta saran pemodifikasi pada aspek kelayakan dalam model 4D. 
Tabel 3 Hasil data dari ahli media dan desain

\begin{tabular}{ccc}
\hline Indikator & Persentase (\%) & Keterangan \\
\hline Desain sampul media uriscrap & 100 & Sangat Sesuai \\
\hline Desain isi media uriscrap & 86,67 & Sangat Sesuai \\
\hline Rata-rata & 93,33 & Sangat Sesuai \\
\hline
\end{tabular}

Data dari ahli media dan desain terhadap media uriscrap pada tabel 3 menunjukkan hasil uji kelayakan terhadap media dan desain diperoleh data sebesar 93,33\% dengan kriteria sangat sesuai. Kriteria sangat sesuai dapat diartikan bahwa penilaian media dan desain dalam produk uriscrap telah layak dan tidak revisi (Handayani, Yuwono, and Madja 2013).
Kelayakan media dan desain pada media uriscrap dilakukan dengan memperhatikan komentar dan saran dari ahli media dan desain serta prinsip desain media berbasis visual (Arsyad 2013) yang terdiri dari prinsip kesederhanaan, keterpaduan, penekanan, dan keseimbangan sebagai proses dari kelayakan media dan desain dalam media uriscrap.

Tabel 4 Hasil data dari ahli format

\begin{tabular}{lcc}
\hline \multicolumn{1}{c}{ Indikator } & Persentase (\%) & Kriteria \\
\hline Kesesuaian isi & 91,67 & Sangat sesuai \\
\hline Kesesuaian desain & 100 & Sangat sesuai \\
\hline Kesesuaian komponen & 100 & Sangat sesuai \\
\hline \multicolumn{1}{c}{ Rata-rata } & 97,22 & Sangat sesuai \\
\hline
\end{tabular}

Data dari ahli format dalam media uriscrap pada tabel 4 menunjukkan hasil uji kelayakan terhadap format diperoleh data sebesar 97,22\% dengan kriteria sangat sesuai. Kriteria sangat sesuai dapat diartikan bahwa format dalam produk uriscrap telah layak dan tidak revisi (Handayani, Yuwono, and Madja 2013). Proses kelayakan format pada media uriscrap berlangsung dengan memperhatikan komentar dan saran dari ahli format.

\section{PEMBAHASAN}

Uji kelayakan media uriscrap sebagai media pembelajaran dilakukan berdasarkan model pengembangan 4D (Sivasailam Thiagarajan, Semmel, and Semmel 1974) yang harus melalui penilaian ahli sebagai proses keberhasilan dari uji kelayakan produk yang dikembangkan sebelum nantinya diuji cobakan dan digunakan. Uji kelayakan media uriscrap berdasarkan teknik penilaian model pengembangan 4D dapat dideskripsikan sebagai berikut:

\section{Materi dan bahasa}

Kelayakan materi dan bahasa sebagai konten/isi dalam media uriscrap disajikan berdasarkan kesesuaiannya dengan KI dan KD sebagai penunjuk dan penentu arah tujuan dari media uriscrap yang diperuntukkan untuk matapelajaran IPA pada siswa kelas VII SMP dengan pemerolehan data sebesar $96 \%$ dengan kriteria sangat sesuai (Handayani, Yuwono, and Madja 2013). Penilaian kelayakan materi dan bahasa berdasarkan (S. Thiagarajan, Semmel, and Semmel 1974) menunjukkan materi cakupan dapat dikatakan layak apabila materi telah sesuai dengan tujuan pembelajaran pada matapelajaran IPA SMP kelas VII. Kesesuaian materi dengan tujuan pembelajaran merupakan salah satu pernyataan pada indikator kesesuaian materi dengan $\mathrm{KI}$ dan $\mathrm{KD}$ dengan pemerolehan data sebesar $100 \%$ dengan kriteria sangat sesuai (Handayani, Yuwono, and Madja 2013). Kesesuaian materi cakupan dalam media uriscrap dengan tujuan yang ingin dicapai juga 
menjadi dasar dalam prinsip pemilihan media (Sanjaya 2008).

Penyajian materi dalam media uriscrap disajikan mengikuti alur dari mudah ke sulit, dari umum ke khusus, serta dari yang dikenal ke asing dengan pemerolehan data sebesar $87 \%$ dengan kriteria sangat sesuai (Handayani, Yuwono, and Madja 2013). Selain itu, penyajian materi dalam media uriscrap disajikan dengan penulisan bahasa yang jelas, sederhana, tidak mengandung arti ganda, dan memiliki hubungan timbal balik untuk setiap kalimatnya. Hal ini bertujuan untuk menyesuaikan tingkat perkembangan intelektual dan emosional siswa dengan pemerolehan data terhadap kelayakan bahasa sebesar 91,43\% dengan kriteria sangat sesuai (Handayani, Yuwono, and Madja 2013). Hal ini sesuai dengan penyajian buku teks berdasarkan penelitian (Ramdani 2015) yang menyatakan, "Penjelasan materi menggunakan bahasa yang sederhana, tidak multi tafsir dan relatif sesuai dengan kognitif pembaca umumnya."

\section{Media dan desain}

Kelayakan media dan desain pada proses pengembangan media uriscrap bertujuan untuk meninjau dan memeriksa kualitas teknis dalam media uriscrap. Kegiatan ini dilakukan setelah materi dan bahasa cakupan dalam media uriscrap telah tervalidasi sebelumnya. Kelayakan media dan desain pada produk media uricrap meliputi bab interaksi makhluk hidup dengan lingkunganya, pencemaran lingkungan, pemanasan global, struktur bumi dan dinamikanya, dan tata surya. Media uriscrap sebagai media pembelajaran dapat diklasifikasikan sebagai media visual berdasarkan sifatnya, sebagai media dengan kemampuan jangkauan yang luas dan serentak berdasarkan kemampuan jangkuannya, dan sebagai media nonproyeksi berdasarkan cara atau teknik pemakaiannya (Sanjaya 2008).

Kelayakan media dan desain uriscrap menekankan pada kemenarikan desain dan kemudahan penggunaannya sebagai media pembelajaran berbasis visual dengan pemerolehan data sebesar 93,33\% dengan kriteria sangat sesuai (Handayani, Yuwono, and Madja 2013). Kemenarikan desain scrapbook yang menekankan pada unsur kreatifitas menjadikan media scrapbook sebagai media yang menarik dan mudah digunakan sehingga dapat membangkitkan motivasi siswa (Sari, 2017). Sejalan dengan prinsip motivasi belajar (Hamalik 2014) yang menyatakan bahwa motivasi yang kuat hubungannya dengan kreativitas. Selain itu, kemenarikan media scrapbook sebagai media berbasis visual dapat menumbuhkan minat siswa dan memberikan hubungan yang nyata mengenai isi materi yang dipelajarinya (Arsyad 2013). Minat yang dapat ditunjukkan dengan adanya penggunaan media uriscrap diperoleh hasil sebesar 95,75\% dengan kriteria sangat kuat (Handayani, Yuwono, and Madja 2013) pada indikator kecukupan kemasan. Pengemasan materi dan gambar dalam media uriscrap pada dasarnya dikemas untuk menarik perhatian dan partisipasi siswa dalam proses pembelajaran.

\section{Format}

Kelayakan format pada proses pengembangan media uriscrap bertujuan untuk meninjau dan memeriksa format atau kerangka dalam media uriscrap, baik secara isi maupun tampilan. Kelayakan format disajikan berdasarkan kesesuaian terhadap isi, desain, dan komponen. Pendeskripsian pada indikator kesesuaian isi diperoleh data sebesar $91,67 \%$ dengan kriteria sangat sesuai, sehingga materi dalam media uriscrap dapat dikatakan telah mampu dalam mengilustrasikan materi melalui gambar serta telah sesuai dalam penyusunan struktur tujuan dan kerangka isi dalam media uriscrap. Indikator kesesuaian desain diperoleh data sebesar $100 \%$ dengan kriteria sangat sesuai, sehingga desain dalam media uriscrap dapat dikatakan telah sesuai dengan tujuan pengembangan dan karakteristik siswa sebagai media yang 
menekankan pada kegiatan seni menempel. Indikator kesesuaian kompenen diperoleh data sebesar $100 \%$ dengan kriteria sangat sesuai, sehingga komponen dapat dikatakan telah sesuai dengan cakupan komponen media yang telah ditetapkan dalam media uriscrap yang dikembangkan berdasarkan (Sari, 2017) dan pemodifikasian peneliti.

Format dalam media uriscrap sebagai media pembelajaran diadaptasi dari prinsip pemilihan dan penggunaan media yang harus sesuai dengan tujuan pembelajaran yang ingin dicapai, berdasarkan konsep yang jelas, kesesuaian dengan karakteristik siswa dan gaya belajar siswa dan guru serta kemampuan guru dalam menggunakannya (Sanjaya 2008).

\section{KESIMPULAN}

Uji kelayakan media uriscrap berdasarkan model pengembangan 4D menunjukkan bahwa media uriscrap telah layak untuk diujicoba sebelumnya nantinya digunakan sebagai media pembelajaran dalam proses pembelajaran IPA. Hasil uji kelayakan media uriscrap memperoleh data sebesar $91,11 \%$ untuk kelayakan berdasarkan aspek materi dan bahasa, sebesar 93,33\% untuk kelayakan berdasarkan aspek media dan desain, dan sebesar 97,22\% untuk kelayakan berdasarkan aspek format.

\section{SARAN}

Penelitian terhadap uji kelayakan media uriscrap (uri scrapbook) dapat dijadikan pertimbangan sebagai media pembelajaran yang dapat dilanjutkan untuk diuji cobakan sebelum nantinya dapat digunakan sebagai media pembelajaran dalam proses pembelajaran IPA.

\section{REFERENSI}

Ariyani, N. O. and Siradjuddin (2014) 'Penggunaan Media Buku Tempel Dalam Model Pembelajaran Langsung Untuk Meningkatkan Hasil Belajar Siswa Kelas IVB Sekolah Dasar', JPGSD, 2(1), pp. 1-12.
Available at:

http://jurnalmahasiswa.unesa.ac.id/ind ex.php/jurnal-penelitian-

pgsd/article/view/10682.

Arsyad, Azhar. 2013. Media

Pembelajaran. Revisi. Jakarta:

Rajawali Pers.

BNSP. 2014. Revitalisasi Peran BSNP Dalam Peningkatan Mutu Pendidikan Nasional Melalui Pengembangan Standar Dan Penyelenggaraan Ujian Nasional Yang Kredibel. http://bsnpindonesia.org/wpcontent/uploads/2014/12/BuletinEdisi-3-2014.pdf.

Fitrianthi, S. D. (2013) Penggunaan Media Scrapbook (Buku Tempel) Untuk Meningkatkan Pemahaman Siswa Terhadap Pembelajaran Membaca Novel Remaja. Universitas Pendidikan Indonesia. Available at: http://skripsi.co/skripsi-sastraindonesia/penggunaan-mediascrapbook-buku-tempel-untukmeningkatkan-pemahaman-siswaterhadap-pembelajaran-membacanovel-remaja-riset-eksperimenterhadap-pelajar-kelas-viii-6-smpn16-bandung-tahun-ajaran-2012/.

Hamalik, Oemar. 2014. Kurikulum Dan Pembelajaran. Jakarta: Bumi Aksara.

Handayani, Izmi, Ipung Yuwono, and Mimiep S. Madja. 2013. "Pengembangan Media Pembelajaran Berbantuan Komputer Pada Materi Diagram Venn Untuk Siswa Kelas VII SMP." http://jurnalonline.um.ac.id.

Hidayat, M. Yusuf, Ina Rosdiana Lesmanawati, and Djohar Maknun. 2014. "Penerapan Model Pembelajaran Core (Connecting, Organizing, Reflecting, Dan Extending) Terhadap Peningkatan Hasil Belajar Siswa Pada Konsep Ekosistem Di Kelas X SMAN 1 Ciwaringin." Scientiae Educatia 3 (2): 111-24. http://download.portalgaruda.org/artic le.php?article $=447120 \& \mathrm{val}=9461 \&$ tit 
le $=$ Penerapan Model Pembelajaran Core (Connecting, Organizing, Reflecting, Dan Extending) Terhadap Peningkatan Hasil Belajar Siswa Pada Konsep Ekosistem Di Kelas X SMAN 1 Ciwaringin.

Ramdani, Muhamad Syahri. 2015. "Analisis Materi, Penyajian Kebahasaan Dan Kegrafikan Dalam Buku 'Pintar Membaca Arab Gundul Dengan Metode Hikari' Karya Agus Purwanto." Universitas Islam Negeri Sunan Kalijaga. http://digilib.uinsuka.ac.id/19025/.

Safitri, R. H. and Julianto (2017) 'Pengaruh Media Scrapbook Sciencetale Terhadap Hasil Belajar Siswa Materi Proses Daur Air di Sekolah Dasar', JPGSD, 5(3), pp. 1065-1074. Available at: http://jurnalmahasiswa.unesa.ac.id/ind ex.php/jurnal-penelitianpgsd/article/view/19971.

Sanjaya, Wina. 2008. Perencanaan Dan
Desain Pembelajaran. bandung: Kencana Prenada Media Group.

Sari, Liawati Permata. 2017. "Pengembangan Media Scrapbook Dalam Pembelajaran Fisika Pada Materi Tata Surya." Universitas Islam Negeri Raden Intan. http://repository.radenintan.ac.id/3122 I.

Thiagarajan, S., D.S. Semmel, and M. I. Semmel. $1974 . \quad$ Instructional Development for Training Teachers of Exceptional Children: A Sourcebook. ERIC. Indiana: ERIC. https://files.eric.ed.gov/fulltext/ED09 0725.pdf.

Umar (2013) 'Media Pendidikan: Peran dan Fungsinya dalam Pembelajaran', Jurnal Tarbawiyah, 10(2), pp. 126141. Available at: http://download.portalgaruda.org/artic le.php?article $=252206 \&$ val $=6793 \&$ tit le=Media Pendidikan: Peran dan Fungsinya dalam Pembelajaran. 